Ideologen Sayyid Qutb (1906-66) var revolusjonsteoretikeren fremfor noen og grunnlegger av den radikale islamismen. Lar hans tanker seg forene med ideen om demokrati?

\title{
NÅR DEMOKRATI IKKE ER ET ALTERNATIV
}


TEKST: Thomas McNicol

DE ARABISKE LANDENE er styrt av helt eller delvis totalitære regimer. Politisk medbestemmelse og deltakelse, pressefrihet, organisasjonsfrihet, samt et uavhengig rettsvesen mangler. Kritiske røster, innad så vel som utenfra, påpeker at det politiske systemet må endres for å fremme en bærekraftig utvikling. Vestlige land og internasjonale organisasjoner hevder at demokratisering må til for å fremme utvikling. ARAB HUMAN DEVELOPMENT REPORT 2002, som Høigilt drøfter i sin artikkel, vektlegger også demokratisering som en grunnleggende komponent for å nå mål for menneskelig utvikling.

Islamistiske bevegelser i de arabiske landene ønsker ikke det vestlige demokratiet. De hevder at importerte vestlige modeller for politisk, sosial og økonomisk utvikling har vært feilslåtte, og at disse modellene skaper et samfunn preget av materialisme, sekularisme og spirituelt forfall. Både moderate og radikale islamister mener muslimenes utvikling er svært skadelidende under de samfunnsordener som eksisterer i dag. For å gjenreise muslimenes stilling i verden, så vel som tapt identitet og moral, ønsker de å avskaffe det de anser som et vestlig hegemoni. Dette kan kun oppnås ved en tilbakevending til islam. Islamistene legger vekt på islams totalitet, nemlig at islam uadskillelig både er religion og stat. Derfor er det implementeringen av shari' $a$, Guds lov, og dannelsen av den islamske staten som er islamistenes hovedkrav.

Metodene islamistiske grupper benytter for å nå dette målet, er imidlertid svært forskjellige. Et vanlig skille trekkes mellom det moderate flertallet og de med en radikal/militant tilnærming. Den førstnevnte gruppen forfekter en gradvis samfunnsendring gjennom reform nedenfra og opp. Islamiseringen skal skje gjennom opplæring av folket i tillegg til politisk arbeid der det øves press på sittende myndigheter for islamisering av lovverket. Det politiske arbeidet kan også være deltakelse i de formene for demokratiske valg som regimene åpner for, som for eksempel Arbeiderpartiet i Egypt. Den radikale gruppen, som er en betydningsfull minoritet på grunn av sine voldsomme metoder og store mediedekning, hevder at de sittende myndighetene og samfunnene er så håpløst korrupte at kompromiss er uaktuelt. Den eneste effektive metoden er revolusjon, med våpen hvis nødvendig.

I denne artikkelen ønsker jeg å belyse hva den islamistiske ideologen Sayyid Qutb (I906-I966) forfekter som den eneste løsningen for menneskelig utvikling $i$ de arabiske landene, og i resten av verden. Qutbs 
islamistiske ideologi i perioden 1948-54 kan leses som en gienspeiling av en bred islamistisk konsensus, men mer enn noe annet legger den diskurs Qutb fremmer i perioden fra 1954 til hans henrettelse i I966 grunnlaget for radikal islamisme. Ahmad Moussalli refererer til Qutbs senere skrifter som "the gospels of radicalism”, mens Kari Vogt refererer til ham som revolusjonsteoretikeren fremfor noe. ${ }^{\mathrm{I}}$

\section{Demokratiske og islamistiske grunnverdier} Vestlige land og internasjonale organisasjoner ønsker en demokratisering av regimene i de arabiske landene. Ønsket begrunnes med hensynet til menneskelig utvikling i landene. De vil formidle og eksportere demokrati som verdi. Demokrati som verdi kan deles i to hovedkategorier: frihet og likhet. Frihet er uttrykk for prinsippet om kollektivt selvstyre der de individene som danner et politisk fellesskap selv bestemmer innholdet av de beslutningene som de skal rette seg etter. Likhet er uttrykk for prinsippet om borgernes likeverd på den måten at de alle skal ha den samme innflytelse på de bindende

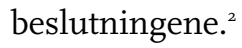

Når radikale islamister ønsker en islamsk revolusjon i sitt hjemland, samt å eksportere revolusjonen til resten av verden, er det fordi de anser at det regierende verdisystemet ikke bidrar til menneskelig utvikling. Samfunnet en skal leve i må være en refleksjon av Guds enhet. Oppgaven Qutb fremsetter for sine tilhengere er å oppdage denne enheten i hele skaperverket, og å handle for å rette opp menneskelig adferd - både individuelt og kollektivt - slik at den samsvarer med all skapelse. ${ }^{3}$ En slik gudelik enhet krever kamp for å virkeliggiøres i verden. ${ }^{4}$ Virkeliggiørelsen skjer gjennom menneskehetens totale underkastelse til den politiske komponenten av Guds enhet, hakimiyyat Allah, Guds absolutte suverenitet og herredømme. Underkastelsen til Guds suverenitet blir uttrykt gjennom etableringen av et islamsk system basert på shari' a. Gjennom dette islamske systemet vil grunnleggende verdier for menneskelig utvikling formidles, nemlig frihet og likhet (likeverd).

Begge de ovennevnte gruppene ønsker en endringsprosess som vil føre til bedrede forhold i de arabiske landene. Førstnevnte fremmer et demokratiseringsprogram, mens sistnevnte fremmer et program for islamsk revolusjon. At begge benytter seg av de samme ordene frihet og likhet som grunnleggende verdier vil ikke tilsi at forståelsen er lik. Jeg vil nå se nærmere på Qutbs forståelse av frihet og likhet, hvorfor han mener ingen samfunn på hans tid inneholdt disse elementene, og hva frihet og likhet vil innebære for menneskene underlagt den samfunnsordenen Qutb fremmer.

\section{Hedendommens slaveri vs. frihet og likhet} Qutb analyserer de rådende samfunnsforholdene og sivilisasjonenes kjennetegn når han legger frem sitt program for dannelsen av en islamsk stat. På bakgrunn av analysen trekker han konklusjonen at alle verdens samfunn i hans egen samtid er jahili - hedenske. 5 Jahilisamfunn er ethvert annet samfunn enn det muslimske. ${ }^{6}$ Jahiliyya er basert på opprør mot Guds herredømme på jord. Disse samfunnene overfører en av Guds viktigste attributter til mannen, nemlig herredømmet, og gjør noen menn til herrer over andre. De mest fremtredende kjennetegnene ved disse samfunnene, ved siden av deres tilrøving av 
herredømmet, er lettsindighet, spesielt av seksuell art. Lettsindighet blir i jahilisamfunn et tegn på frihet. Disse samfunnenes oppfatning av frihet vil ødelegge de moralske verdiene og lovens forordninger slik de fremstår i islam. ${ }^{7}$ Menneskene som lever i et slikt samfunn, og som følger dets normer og verdier uten å ty til motstand eller å ta bevisst avstand fra disse, lever et hedensk liv og er derav de vantro.

Et av Qutbs hovedpostulater i samfunnsanalysen av samtidens jahiliverden er at det verken finnes frihet eller likeverd for menneskene i denne sivilisasjonstypen. Ifølge Moussalli definerer Qutb friheten i samfunnet på en negativ måte. Menneskene er

\section{Mennesket er bare en slave av Gud, og alt annet ville vore mot menneskets natur.}

fri såfremt deres valg av sosiale eller politiske systemer ikke krenker det guddommelige herredømmet og ikke hindrer religiøst liv. For Qutb er det guddommelige herredømmet så altomfattende at det utelukker alt menneskelig herredømme og autoritet. Enhver ikke-guddommelig autoritet er tyrannisk og illegitim. Mer spesifikt betyr Qutbs forståelse av frihet en frihet fra lydighet til et tyrannisk styre, som også beskrives som mangelen på tvang fra et overordnet menneske. Et slikt tyranni er ikke et tilfeldig onde, men en virkelig og indre karakteristikk ved menneskelig herredømme. Frihet er også friheten til å underkaste seg medlemskapet i umma' en - Guds samfunn. På denne måten forstøtes dominansen av lyst og umoral, som i jahilisamfunn er blitt betegnet som frihet.

Likeverd er for Qutb bare mulig under guddommelig herredømme. Hvert medlem av samfunnet er i kraft av sin felles underkastelse for Gud og Hans lovforordninger (shari' a) like. Likheten som forfektes er ikke at alt skal være fullstendig likt i form av rikdom, eiendom og rett til liv, men at man er likeverdige fordi alle på lik måte er underkastet Guds kall. Med andre ord er alle i det islamske samfunnet, som er et samfunn basert på tro, på lik fot under Guds banner.

I jahiliyya mister menneskene friheten og likeverdet som oppnås under den islamske og guddommelige lovgivningen. Ettersom Gud har skapt verden og dens lover, såvel som innsatt mannen som stedfortreder på jorden under sine forordninger, er alle andre systemer unaturlige og hedenske. Mennesket er bare slave av Gud, og alt annet vil være mot menneskets natur. Alle menneskelige handlinger må åpenbare seg som handlinger av gudsdyrkelse, der Guds hensikt blir evig fulgt og stadig fornyet i samfunnet. Hvis en ikke innordner seg dette, innordner en seg jahiliyya. Umoral og dyrisk adferd vil regjere i slike samfunn. ${ }^{8}$

Den ovennevnte forståelsen av frihet og likhet står i motsetning til de demokratiske verdiene frihet og likhet. Den demokratiske verdien frihet, som uttrykker prinsippet om kollektivt selvstyre der individene som danner et politisk fellesskap selv bestemmer innholdet av beslutningene de skal rette seg etter, samsvarer overhodet ikke med Qutbs forståelse av frihet. Ikke fordi den demokratiske frihet utelukker radikal islamisme som en politisk ytring blant flere, men fordi radikal islamisme 
utelukker andre politiske fellesskap og dermed demokratiet. Den demokratiske verdien likhet, som uttrykker prinsippet om borgernes likeverd til den samme innflytelse på bindende beslutninger, kan ved første øyekast ligne Qutbs forståelse av likhet spesielt med tanke på innflytelse på bindende beslutninger ettersom alle underkaster seg Guds beslutning og dermed er den lik. Imidlertid vil kun de borgerne som underkaster seg Gud være likeverdige. Borgere som ikke underkaster seg vil klassifiseres som vantro og mangle grunnleggende menneskerettigheter. De som tilhører jødisk eller kristen trosretning blir kalt Bokens folk. Disse klassifiseres ikke i samme gruppe som de vantro, men blir tilbudt statusen dhimmi (beskyttede) som gir beskyttelse i et islamsk samfunn. For å få statusen av dhimmi må de betale en ekstra skatt, jizya.

Postulatet at de vantro vil mangle grunnleggende menneskerettigheter kan forklares utfra Qutbs syn på sivilisasjon og menneske. Den islamske sivilisasjonen kan ta forskjellige former i materielle og organisatoriske strukturer, men prinsippene og verdiene som den er grunnlagt på er evige og uforanderlige. Dette fordi de skal samsvare med skapelsesfunksjonen:

the worship of God alone, the foundation of human relationships on the belief in the Unity of God, the supremacy of the humanity of man over material things, the development of human values and the control of animalistic desires, respect for the family, the assumption of the viceregency of God on earth according to His guidance and instruction, and all affairs of this viceregency, the rule of God' s law (al-Shari' ah) [sic] and the way of life prescribed by him. ${ }^{9}$

Ettersom mennesket er skapt av Gud, vil det guddommelige lovsystemet med dets moral, prinsipp- og verdisett samsvare med skapelsesfunksjonen gitt til mennesket. Opprettholder ikke mennesket dette lovsystemet, samsvarer ikke mennesket med sin skapelsesfunksjon, og vil derfor ikke være et menneske. ${ }^{10}$ Moralen og verdiene gitt gjennom det guddommelige lovsystemet er trekkene som skiller menneskene fra dyrene. Bare personer Qutb definerer som muslimer vil være mennesker, ettersom de aktivt arbeider for og innretter seg etter sin skapelsesfunksjon. Jahilimennesker vil være som dyr, ettersom de mangler trekkene som gjør dem menneskelige.

\section{Friheten til å velge islam}

Menneskelig frihet går, ifølge Qutb, tapt i jahiliyya. Jahiliyya betyr slaveri under andre menn, mens islam på sin side betyr frihet fra dette slaveriet, ettersom den eneste Herren er Gud. Jihad" er den frigjørende makten som både gir mennesket frihet og muligheten til å danne Guds rike på jor-

\section{En har bare mulighet til å velge islam. Frihet eksisterer kun inn- ordnet $i$ det islamske systemet.}

den. Islam har ikke bare retten til, men plikter å realisere sin form for menneskelig frihet. $^{12}$

Friheten inkluderer også friheten til å velge religion, ettersom sure 2, 256 stadfester at det ikke er tvang i religionen. Trosfrihet er en grunnleggende rettighet for 
mennesker. ${ }^{13}$ Innordnet i Qutbs tolkning av trosfrihet ligger det imidlertid et paradoks; en har egentlig bare muligheten til å velge islam. Frihet eksisterer kun innordnet i det islamske systemet, og individet må først anerkjenne Guds herredømme før en oppnår friheten til å velge. På denne bakgrunnen vil jeg hevde at man gjennom Qutbs islamistiske ideologi bare blir gitt frihet til å velge islam.

Fremgangsmåten for å oppnå et nytt islamsk lederskap er den samme som den første generasjonen muslimer hadde. Først må hedendommen brytes ved å migrere, giennomføre en hijra $^{14}$, og deretter oppfordre til krig mot de som kriger mot det nydannede islamske samfunnet. Tillatelsen gjelder også å kunne krige mot alle vantro frem til Guds religion er fullstendig etablert. Denne kampen for Gud, kalles jihad. Qutb hevder at jihad i islam bare er navnet for kampen som skal giøre det islamske livssystemet dominant i verden. ${ }^{15}$ Metodene for å nå dette målet er preken og overtalelse, samt fysisk makt og jihad. Den islamske jihad er på ingen måte kun et defensivt forsvar for et islamsk hjemland, selv om det også innebærer dette. Det endelige målet for den islamske bevegelsen er å utbre islam over hele verden. Objektet for islam er hele menneskeheten og dens handlingssfære er hele jorden. Årsaken til at en må benytte seg av fysisk makt og jihad for å implementere det islamske systemet og shari' a, er at dette ikke kan bli oppnådd giennom preken alene, jahiliyya vil alltid ty til motstand, ifølge Qutb:

Those who have usurped the authority of God and are oppressing God's creatures are not going to give up their power mere- ly through preaching; if it had been so, the task of establishing God's religion in the world would have been very easy for the Prophets of Allah! This is contrary to the evidence from the history of the Prophets and the story of the struggle of the true religion, spread over generations. ${ }^{16}$

Muslimske menn og gutter, i denne såvel som i kommende generasjoner, må oppdras og utdannes for å innsette et nytt lederskap for menneskeheten, slik Profeten ledet den første generasjonen muslimer. Dette lederskapet oppnås gjennom kamp med jahiliyya. Den eneste effektive metoden for denne kampen er revolusjon og hellig krig. Qutb hevder at utførelsen av jihad mot jahiliyya er en religiøs plikt.

Den eneste valgmulighet som finnes er mellom islam og jahiliyya, mellom godt og ondt. For en som, ifølge Qutb, kan kalle seg en muslim finnes det bare ett parti, Guds parti. Likeledes finnes kun én legitim stat, den islamske stat, der en underkaster seg Guds herredømme. Programmet for medlemmene er enkelt: implementering av det islamske systemet og shari' a, samt utryddelse av jahiliyya ved bruk av jihad.

\section{Qutbs ideologiske innflytelse i dag}

Sayyid Qutb er blant de ideologene som har størst betydning og innflytelse på islamistiske bevegelser og den islamske vekkelsen i den arabiske verden. Ifølge Haddad, er store deler av publikasjonene fra radikale islamister i dag enten inspirert av Qutbs skrifter, plagiat fra bøkene hans eller kommentarer til hans ideer. ${ }^{17}$ Et stort antall bevegelser kan også sies å være direkte avkom av eller sterkt inspirert av hans ideologi. Spesielt gjelder dette radikale islamistiske bevegelser som har oppstått i 
Egypt. Eksempler på slike er Jama' at alJihad (Al-Jihad), bevegelsen som stod bak drapet på president Sadat i I98I og Al-Takfir wa al-Hijra samt flere mindre kjente militante bevegelser. Qutbs ideologi er imidlertid ikke forbeholdt Egypt, men leses og etterfølges av radikale islamister fra Marokko i Vest til Filippinene i Øst. Peter Bergen hevder at Qutbs ideologi har hatt sterk påvirkning på dette årtusenets mest kjente radikale islamistiske gruppering, nemlig al-Qaida-nettverket. ${ }^{8}$ Palestinske Hamas er også inspirert av Qutbs ideologi.

$$
\cdot f \cdot
$$

${ }^{ }$Moussalli, Ahmad S, I997: 73: “Discourses on human rights and pluralistic democracy" i Anders Jerichow og Jørgen Bæk Simonsen (Red.): «Islam in a Changing World: Europe and the Middle East» (ss. 4590), Richmond, Curzon. Vogt, Kari, I994: 2I8: «Islams hus: Verdensreligion på fremmarsj», Otta, J. W. Cappelens Forlag axs.

${ }^{2}$ Statsvitenskapelig leksikon I997.

${ }^{3}$ Euben, Roxanne L, I999: 76: «Enemy in the Mirror: Islamic Fundamentalism and the Limits of Modern Rationalism», New Jersey, Princeton University Press.

${ }^{4}$ Vogt, I994: 2 I7.

${ }^{5}$ Jahiliyya-begrepet karakteriserer den hedenske ignoranse som skal ha vært kjennetegnet på de før-islamske samfunn på den arabiske halvøy. Sayyid Qutb og blant andre Mawdudi bruker begrepet som en ahistorisk karakteristikk på alle samfunn som ikke har underlagt seg Guds herredømme (hakimiyya) og som ikke har implementert Guds lov (shari' a). Samfunnet er jahili så lenge disse forordningene ikke er overholdt, selv om det er muslimer som leder samfunnet. Qutb hevder imidlertid at disse muslimene ikke er muslimer fordi de ikke danner et islamsk samfunn, men fortsetter å opprettholde jahiliyya.

${ }^{6}$ Qutb, Sayyid, I978: I48: «Milestones (Large font version)», oversetter ikke oppført, Salimiah, International Islamic Federation of Student Organizations.

${ }^{7}$ Qutb, Sayyid, 200I: 72: «In the Shade of the Qurí an (Vol. 3)», oversatt av: A. A. Shamis og M. A. Salahi, Leicester, The Islamic Foundation.

${ }^{8}$ Qutb, I978: I78-I79.

9Ibid, I978: 196.

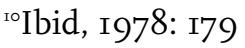

"Jihad, “anstrengelse”, “streben”, hellig krig. Beskriver ethvert initiativ til forbedring i samsvar med islamske prinsipper og bekjempelse av forfall. Begrepet beskriver også væpnet kamp i form av hellig krig, men i hovedsak som et defensivt forsvar. Radikale islamister med Sayyid Qutb som hovedtalsmann hevder at de som anser jihad kun som et defensivt middel ikke forstår islam. Selv om jihad også innebærer det defensive forsvar, så er jihad også en offensiv kamp for etableringen av islamske samfunn overalt hvor de ikke eksisterer og for å utrydde jahilisamfunnene.

${ }^{\mathrm{I}} \mathrm{Qutb}$, I978: 93-I40. 
${ }^{13}$ Qutb, Sayyid, I999: 325: «In the Shade of the Qurí an (Vol. I)», oversatt av: A. A. Shamis og M. A. Salahi, Leicester, The Islamic Foundation.

${ }^{14} \mathrm{Hijra}$, "brudd", "migrasjon". Betegner i første rekke profeten Muhammad og hans trosfellers migrasjon fra Mekka til Medina i 622 e. Kr, hvor Muhammad etablerte et islamsk samfunn. Betydningen av denne migrasjonen stadfestes ved at det er denne som er utgangspunktet for den islamske tidsregningen. Qutb hevder at en slik migrasjon er et nødvendig skritt for å danne et islamsk samfunn eller stat også i hans samtid. Dette fordi Profetens veiledning og program, ifølge Qutb, ga muslimene retningslinjer $\mathrm{i}$ fortiden såvel som den gir veiledning i nåtiden og vil gjøre det i fremtiden.

${ }^{15}$ Qutb, 1978: 139.

${ }^{16}$ Qutb, 1978: 105 .

${ }^{17}$ Haddad, Yvonne Y, I983: 8I, "Sayyid Qutb: Ideologue of Islamic Revival”, i Esposito, John L. (Red.), «Voices of Resurgent Islam» (ss. 67-98), New York, Oxford University Press.

${ }^{18}$ Bergen, Peter, 200I: «Holy War, Inc: Inside the Secret World of Osama bin Laden», New York, Free Press 